\title{
Number of Animals Used in Experiments in 1975
} - Results of a Survey -

\author{
Experimental Animal Survey Committee \\ Chairman : Daizo Ushiba, Keio University School of Medicine
}

\begin{abstract}
A survey on the number of animals used in experiments including bioassay, diagnosis, education and preparation of biological agents such as vaccines between April 1975 and March 1976 was conducted by the support of a grant-in-aid for the specific research, "Purification and Development of Experimental Animals", from the Ministry of Education, Science and Culture of Japan. Of 933 universities, institutes, hospitals, testing laboratories and companies, 648 replies were received. As shown in the table, a total of 57,107,553 animals were used for various experiments in Japan in 1975. The distribution of the number to animal species is also shown in the table. Comparing with the similar surveys in 1956, 1960, and 1970 (Exp. Anim., 7, 3-8,1958, 12, 145-168, 1963, and 22, 307-340, 1973), the number of animals used in Japan seems to have reached a roughly constant level. Periodic surveys should be continued as a nation wide project for medical and biological sciences.
\end{abstract}

Number of Animals Used in Experiments in 1975

$\begin{array}{lrlr}\text { Mice } & 9,670,235 & \text { Other mammalia } & 155 \\ \text { Rats } & 1,611,445 & \text { Chikens } & 185,769 \\ \text { Hamsters } & 32,543 & \text { Japanese quail } & 17,631 \\ \text { Guinea pigs } & 149,438 & \text { Other fowls } & 18,867 \\ \text { Other rodents } & 5,245 & \text { Eggs } & 30,525,065 \\ \text { Rabbits } & 184,371 & \text { Reptiles } & 1,518 \\ \text { Dogs } & 53,142 & \text { Amphibians } & 135,564 \\ \text { Cats } & 12,963 & \text { Fishes } & 196,376 \\ \text { Pigs } & 1,580 & \text { Insects } & 10,906,980 \\ \text { Other domestic animals } & 15,996 & \text { Other invertebrates } & 3,378,816 \\ \text { Primates } & 3,884 & \text { (Total) } & 57,107,553\end{array}$

\section{5年度に実験に使われた動物の数}

\author{
文部省科学研究費特定研究「実験動物の純化之開発」実験動物使用数調査班 \\ 班長：荦応義檠大学 牛 場 大 蔵
}

実験用動物の使用数に関する全国調査は，1956年日本 実験動物研究会 $[1], 1960$ 年日本医学会 $[2], 1970$ 年 文部省科学研究費補助金による日本学術会議実験動物研 究連絡委員会と日本実験動物研究会の協力 [3]によっ
て実施されている。この調査は，その時代の実験用動物 に関する諸々の資料を提供するばかりでなく，その後の 実験動物の進展を計る重要な情報源となるので, 定期的 にくりかえされる必要がある。幸い, 1975年における実 
験用動物使用数調査を, 文部省科研費特定研究「実験動 物の純化と開発」基礎班の研究の一部としておこならこ とができた。調査についての大まかな中間集計はすでに 報告したが [4]，今回その最終集計とともに詳しいま とめを以下に記述しておく。

\section{I. 調 查方 法}

\section{1. 調查組織}

この調査は「文部省特定研究：実験動物の純化と開 発」基礎班（代表者 吉田俊秀）の中に設けられた調査 班（班長 牛場大蔵）によって実施された。

実験用動物使用数調查班

慶応大医 牛場大蔵（基礎班々員）

遺伝研吉田俊秀（"l）

阪大微研 川俣順一（" l )

名大農近藤恭司（＂）

日獣畜大 田嶋嘉雄（＂））

慶応大医 前島一淑（幹事）

"l 岸本好雄 ( " ) )

\section{2. 調查方法}

調査の方法は，1970年度使用数調查［3] のそれとほ とんど同じであるが，今回は使用目的別（研究用, 製造 用）の集計はおこなわなかった。参考までに，各調查機 関に依頼した調査用紙の記入要領をかかげておく。

1.この調査の対象となる期間は, 昭和50年(1975年) 4 月 1 日から昭和51年 (1976年) 3 月31日までです。

2. 使用数とは, 機関 (大学々部, 研究所等) 単位 で，研究・検定・検査・教育・診断・ワクチン製造 などに用いたすべての匹数を意味します。この際， 自家生産したものも上記目的に使用のものは含まれ ますが，生産後他機関へ供給したものは含まれませ ん。

3. 記入用紙は I (ピンク), II (ブルー) の 2 種類 があります。

4. 記入用紙 I （ピンク）はマウスおよびラットのた めの用紙です。

（1）ふつらの名前：マウスまたはラットと記入して 下さい。

（2）系統名：使用した動物の系統名を記入して下さ い。

（3） 使用数 : 上記 2 参照

（4） 備考：参考になることがあれば記入して下さ い。
5. 記入用紙 II （ブルー）はマウス・ラット以外の動 物のための用紙です。哺乳動物・トリ類・発育卵・ は虫類・両棲類・魚類 · 円口類 - 無脊椎動物などす ベてを含みます。

（1）ふつらの名前：ふつらの種名（日本名，たとえ ばモルモット，カニクイザル，ニワトリ，メダ カ, ショウジョウバエなど）を記入して下さい。 （日本名で妥当なもののない時は英名その他の外 国名）

（2）学名：特殊な動物についてのみ, 国際学名を記 入して下さい。

（3）品種・系統名・突然変異記号など：もしあれば 記入して下さい。

（4） 使用数：上記 2 参照

（5） 備考：参考になることがあれば記入して下さ い。

6. 各記入用紙とも，2枚以上になるときは，右下欄 外の枚数のところに記入して下さい。

7. 御返送は昭和51年10月30日までに下記宛願い上げ ます（返信用封筒同封いたしました）。

干 160 東京都新宿区信濃町35

慶大医学部微生物学教室内 実験用動物使用数調查班

8. 本調查について 御不審の点は事務局（03-3531211 , 内線 2690 牛場, 内線2695岸本, 内線2692前島） までお問合せ下さい。

調査対象とした機関は, 大学では医, 歯, 薬, 栄養, 獣医, 畜産, 水産, 動物, 心理の学科ないし講座をもつ 学部之付置研究所（短大を除く），公的研究所では上記 学問領域を研究対象としているところ（国，地方自治 体, 法人), 大きな病院ないし国立療養所, 製薬, 食品, 包装器材, 化粧品その他の企業で，その選定には下記の 書を参考とした。

$\begin{array}{ll}\text { 全国大学職員録 } & 1976 \text { (広潤社) } \\ \text { 全国研究機関総覧 } & 1974 \text { (学術会議) } \\ \text { 医育機関名簿 } & 1975 \text { (中外製薬) } \\ \text { 医学研究者名簿 } \quad 1972 ７ 3 \text { (医学書院) } \\ \text { 会員名簿 （日本製薬工業協会） } \\ \text { 普通会員名簿（実験動物研究会） } \\ \text { Medical Pocket Diary 1976 (医学書院) }\end{array}$

\section{II. 調 查 成 績}

1. 調查用紙の回収 
調査用紙は大学 363 機関, 公的研究所 153 機関, 病院 - 療養所 275 機関, 企業研究所 142 機関の計 933 力所に 送られ，648 力所より回答がえられた（回収率 648/933 =69.5\%)。これをすこし細かくながめると，大学医・ 歯・薬学部の回答は $110 / 136=80.9 \%$, 農・獣医・水産 学部は $36 / 44=81.8 \%$, 理学部は $33 / 43=76.7 \%$, 文・教 - 家政学部は $73 / 102=71.6 \%$, 大学付置研究所は $28 / 38$ $=73.7 \%$, 国立研究所は $27 / 36=75.0 \%$, 地方自治体研 究所は $64 / 81=79.0 \%$, 法人研究所は $26 / 36=72.2 \%$, 病 院・療養所は $158 / 275=57.5 \%$, 企業研究所は $93 / 142=$ $65.5 \%$ であった。企業については製薬, 食品, 包装器 材，化粧品等にわけて集計することが考慮されたが，業 務内容が多岐にわたる機関も多く，業種の分類がむつか しいので, あえて企業研究所と一括記載した。

なお，1956年，1960年，1970年度調查に扣ける回収率 はそれぞれ $132 / 182=72.5 \% ， 2412 / 2907=82.9 \% ， 883 /$ $1310=67.4 \%$ あっあた。

\section{2. 実験使用動物名}

実験に使われた動物の種類は調査用紙に記されたもの をみると，その数はきわめて多い。これらの個々を示す ことは繁雑に過ぎる感があるが, 実験用動物の範囲を概 観するため，回答に記人されていたすべての動物名その ものを五十音順にら列しておく。この場合，たとえば 「ゴキブリ」といら記載と「ワモンゴキブリ」,「ヤマト ゴキブリ」など種名にわけた記載があったが，動物名と しては両方ともあげてある。また, 種名（系統・品種名 など）については疑わしい例もあるが，とくに強い理由 がないかぎり回答者の記述をそのまま採用している。な お1970年度調査報告 [3]においては,これについての 詳細な分類と記載がなされている。

アオイトトンボ・アオガイ・アオガエル・アオダイシ ョウ・アオリイカ・アカイエカ・アカウニ・アカゲザル ・アカテガニ・アカネズミ・アカハライモリ・アカムシ ・アゲハ・アサリ・アジ・アジルテナガザル・アズキゾ ーリムシ・アナグマ・アナンダレー・アヒル・アブラム シ・アフリカツメガエル・アフリカマイマイ・アフリカ ミドリザル・アプリジア・アマオブネガイ・アマガイ・ アマガエル・アメフラシ・アメリカザリガニ・アメリカ フジッボ・アメーバ・アュ・アリモドキゾームシ・アル テミア・アルマジロ・アワトウモウガ・アワビ・イエカ ・イエコウモリ・イエバエ・イカ・イガイ・イシガメ・ イシガレイ・イシダイ・イシマキガイ・イセエビ・イソ アワモチ属・イタチ・イトマキヒトデ・イトヨ・イナゴ ・イナツマヨコバイ・イヌ・イノシシ・イボダイ・イボ
ニシ・イモリ・インディアンマーモセット・インドクマ ネズミ・インドスナネズミ・ウ・ウグイ・ウサギ・ウシ ・ウシガエル・ウスカワミジンコ・ウズラ・ウッボ・ウ ナギ・ウニ・ウマ・ウマヅラハギ・ウミニナ・ウメボシ イソギンチャク・エゾアカネズミ・エゾスジグロチョウ ・エゾバフンウニ・エゾヒメネズミ・エゾヤチネズミ・ エビナガコウモリ・エンゼルフィツシュ・エンマコオロ ギ・オイカワ・オオガラゴ・オオクロヤブカ・オオジュ リン・オオスカシバ・オオミジンコ・オオヤドカリ・オ カダンゴムシ・オタマジャクシ・オナガ・オナジマイマ イ・オニテナガエビ・カ・カイコ・カキ・カサガイ・ガ ザミ・カシラダカ・カタクチイワシ・カタツムリ・カダ ヤシ・ガチョウ・カツオブシムシ・カナヘビ・カナリヤ ・カニ・カニクイザル・カブトガニ・カブトヘビ・カメ ・カメノテ・カヤネズミ・カラス・カラスアゲ八・カラ スガイ・カワトンボ・カワニナ・カワハギ・カンザワハ ダニ・カンシャクカメムシ・キジ・キジバト・キタテハ ・キタネグサレセンチュウ・キュウカンチョウ・魚卵・ キンギョ・キンパラナガハシカ・ギンハト・ギンブナ・ クサガメ・クジャクバト・グッピー・クモ・クリオオア ブラムシ・クルマエビ・クロイソカイメン・クロキンバ エ・クロクビタマリン・クログチ・クロゴキブリ・クロ ヘリアメフラシ・クロベンケイガニ・クロマグロ・クロ ミミマーモセット・ケナガコナダニ・ゲンゴロウブナ ・ コイ・コウマダラエダシャク・コウメオウメミジンコ・ コガタアカイエカ・ゴキブリ・コクヌストモドキ・コバ ネナガカメムシ・コベルトフネガイ・コモリガエル・コ モリクモ・コモンゴキブリ・コモンツパイ・コモンマー モセット・ゴンズイ・ゴールデンハムスター・サカハチ チョウ・サカマキガイ・サケ・サザエ・サツマイモネコ ブセンチュウ・サトキマダラヒカゲ・サバ・ザリガニ・ サワガニ・サワラ・サンゴイソギンチャク・サンショウ ウオ・シイラ・ジェフロイタマリン・シチメンチョウ・ シナハマダラカ・シマドジョウ・シマハゼ・シマヘピ・ シマミミズ・ジムグリ・ジャガイモガ・シャコ・ジャコ ウネズミ・ジャンガリアンハムスター・ジュウシマツ・ ショウジョウバエ・ショウジンガニ・シルバーマーモセ ット・シロアシネズミ・シロテテナガザル・シロボヤ・ ジンサンシバムシ・水棲昆虫・スジエピ・スジグロチョ ウ・スズガエル・スナネズミ・スルメイカ・スローロリ ス・セイロンクマネズミ・セキセイインコ・セジロウン カ・ゼブラダニオ・セミ・センチニクバエ・センモウチ ュウ・ゾウハナウオ・ソードテール・ゾーリムシ・タイ ラギ・タイワンザル・タコ・タゴガエル・タチウオ・タ 
ツナミガイ・タップミノー・タテジマイソギンチャク・ タナゴ・タニシ・ダニ・タヌキ・タマゴ(綇卵)・ダルマ ガエル・チカイエカ・チチブ・チリカブリダニ・チャイ ニーズハムスター・チャコカクモンハマキ・チャバネゴ キブリ・チュウベイクモザル・チンチラ・チンパンジー ・ツチガエル・ツナイモッゴ・ツハコウカイガラムシ・ ツマグロヨコバイ・ティラピア・テントウムシ・トウゴ ウヤブカ・トウメイナマズ・動物プランクトン・トカゲ ・トゲアメフラシ・ドジョウ・トノサマガエル・トノサ マバッタ・トビイロウンカ・トビイロゴキブリ・ドブガ イ・トヨミ・トリプテロイド属カ・ナキウサギ・ナメク ジ・ナマズ・ナミ八ダニ・ナンキンムシ・ナンヨウクマ ネズミ・ニカメが・ニカイイュウ・ニクバエ・ニシ キガメ・ニジマス・ニセナミハダニ・ニホンアカガエル ・ニホンクマネズミ・ニホンザル・ニホンドウソコエビ ・ニホンハツカネズミ・ニホンザルメヤクニホンザル・ ニワトリ・ヌタウナギ・ヌマガイ・ヌートリア・ネコ・ ネッタイイエカ・ネッタイシマカ・熱带魚・ノウサギ・ ノドジロオマキザル・ノルドマンエボシミジンコ・ハイ イロゴキブリ・ハエダニ・ハエトリグモ・ハコフグ・八 サミムシ・ハシボソカラス・八スモンヨトウ・八ゼ・八 チミツガ・ハツカネズミ・ハト・パタスモンキー・ハチ ・バッタ・バフンウニ・ハマグリ・八マチ・バン・バン デレウリア・ヒオウギガイ・ヒキガエル・ヒザラガイ・ ヒダリマキマイマイ・ヒツジ・ヒトデ・ヒドラ・ヒバリ ガイ・ヒブナ・ヒメコクヌストモドキ・ヒメジヤコガイ ・ヒメタニシ・ヒメダカ・ヒメトビウンカ・ヒメナガカ メムシ・ヒメネズミ・ヒメマス・ヒメモノアラガイ・ヒ メルプシス・ピューマ・ヒョウ・フェレット・フクラス ズメ・フサオマキザル・フトシマフサカ・フトツメダニ ・フトミミズ・ブタ・ブタオザル・フナ・フナムシ・フ ラミンゴ・プラスティリックス・プラナリア・ブリ・ヘ ナタリ・ベニガオザル・ホウボウ・ホッカイエビ・ホホ ジロ・ボラ・ホロホロチョウ・ホンコンクマネズミ・ホ ンベラ・ボンネットモンキー・マウス・マイコアカネ・ マカカ属ザル・マカカ交雑群・マガキガイ・マガモ・マ キガイ・マス・マストミス・マナマコ・マハぜ・マブナ ・マボヤ・マメアブラムシ・マングース・マントヒヒ・ ミカン八ダニ・ミズトリ・ミジンコ・ミッバチ・ミドリ ガメ・ミドリザル・ミドリザルメバタスモンキー交雑群 ・ミドリゾーリムシ・ミドリムシ・ミナミネグサレセン チュウ・ミノウミムシ・ミミエガイ・ミミズ・ミャイリ ガイ・ミラルデイア・ミンク・ムギコナダニ・ムギヒゲ ナガアブラムシ・ムクドリ・ムラサキイガイ・ムラサキ
ウニ・ムーアモンキー・メジナ・メダカ・モノアライガ イ・モルモット・モンシロチョウ・ヤギ・ヤクニホンザ ル・ヤコンオサムシ・野生メダカ・ヤツメウナギ・ヤブ カ・ヤブカグループ・ヤマカガシ・ヤマキマダラヒカゲ ・ヤマトゴキブリ・ヤマトヤブカ・ヤマメ・ヤマヒドラ ・ヤモリ・ヤンマ・ユウレイボヤ・ユスリカ・ヨウシュ クマネズミ・ヨザル・ヨシノボリ・ヨーロッパ産ウナギ ・ラット・ラッパウニ・リス・リスザル・リバースシマ カ・リュウキュウハト・リンゴコカクモンハマキ・ロブ スター・ワタボーシタマリン・ワタボーシパンシェ・ワ ニ・ワモンゴキブリ。

3. 実験使用動物の系統・品種・種名の集計

回答された調査用紙には各種動物の系統, 品種別が多 数記されているが，それらの中には明らかに同一と思わ れるものが, 異った名称で記されている例がある。それ らをでき得る限り整理して, 各動物種別に, 各機関ごと に区分して一覧表としたのが，表 1 表 9 であり，系 統，品種等にかかわらず各動物種のレベルでまとめたの が表10である。表中の系統名以外に，なお多くの名称が 回答されているが（たとえばマウスでは 491，ラットで は84,モルモットでは14の異なった名称が回答された), それらは適当と思われる表中の系統名に入れて集計され ている。

\section{III. ま とめ}

1975年度（1975．4．1～1976.3. 31）に研究, 検定, 検査, 教育, 診断, ワクチン製造などに用いられたすべ ての動物の数を, わが国の 933 機関に問合せ, 648 機関 より回答を得た。その合計はマウス 9,670,235, ラット $1,611,425$, 八ムスター類 37,788, モルモット 149,438 , ウサギ184,371, イヌ53,142, ネコ12,963, サル類3,884, ニワトリ185,769, タマゴ 30,525, 065 などでその他の動 物をふくめた統計は57,107,553であった。これらの数值 は個々について細かくみれば多少の変動はあるが, 1970 年度の調査值 $[3]$ とほぼ同じとみてよい。つまり巨視 的にいえば，わが国の実験用動物の使用数はほぼ一定に なってきているようである。しかしこの推移は各動物種 について今後も継続して判定しなければならないし，そ れによってはじめて実験動物のあり方に関する示啐も生 れてくるものと思われる。また諸外国における同様な調 查との比較によって，実験動物の世界的動向を察知する ことができるであろう。

いずれにしてもこの種の調査は定期的に一定の調査方 
式によって，くり返される必要があり，このためには少 なくとも約 5 年ほどの間隔が望まれる。同時に, 得られ る数值の信頼性の向上, より効果的で無駄のない調査方 法の確立のために, 基礎的な研究を行らことが緊要であ ろら。

終りに調査に協力された全国の各機関の方々に深甚の 謝意を表する。また調査, 集計の途中に種々有益なご示 唆をいただいたことを併せて感謝する。

この調查は文部省科研費特定研究「実験動物の純化と 開発」基礎班（昭和51年度）の援助によって行われた。

\section{文献}

1. 安東洪次 (1958)：わが国の実験動物の現状について。実 験動物, 7, 3-8

2. 日本医学会動物実験現状調查会（1960）：日本に拈ける動 物実験の現状.

3. わが国における実験動物の生産, 供給についての調查・研 究班 (1973）：実験につかわれた動物種ならびにその数一 1970年度の調查結果から一。実験動物, $22,307-340$.

4. 牛場大藏 (1977)：実䜽動物に関する調查, 昭和51年度文 部省科研費による特定研究「実験動物の純化と開発」研究 報告集録, pp.90 92. 


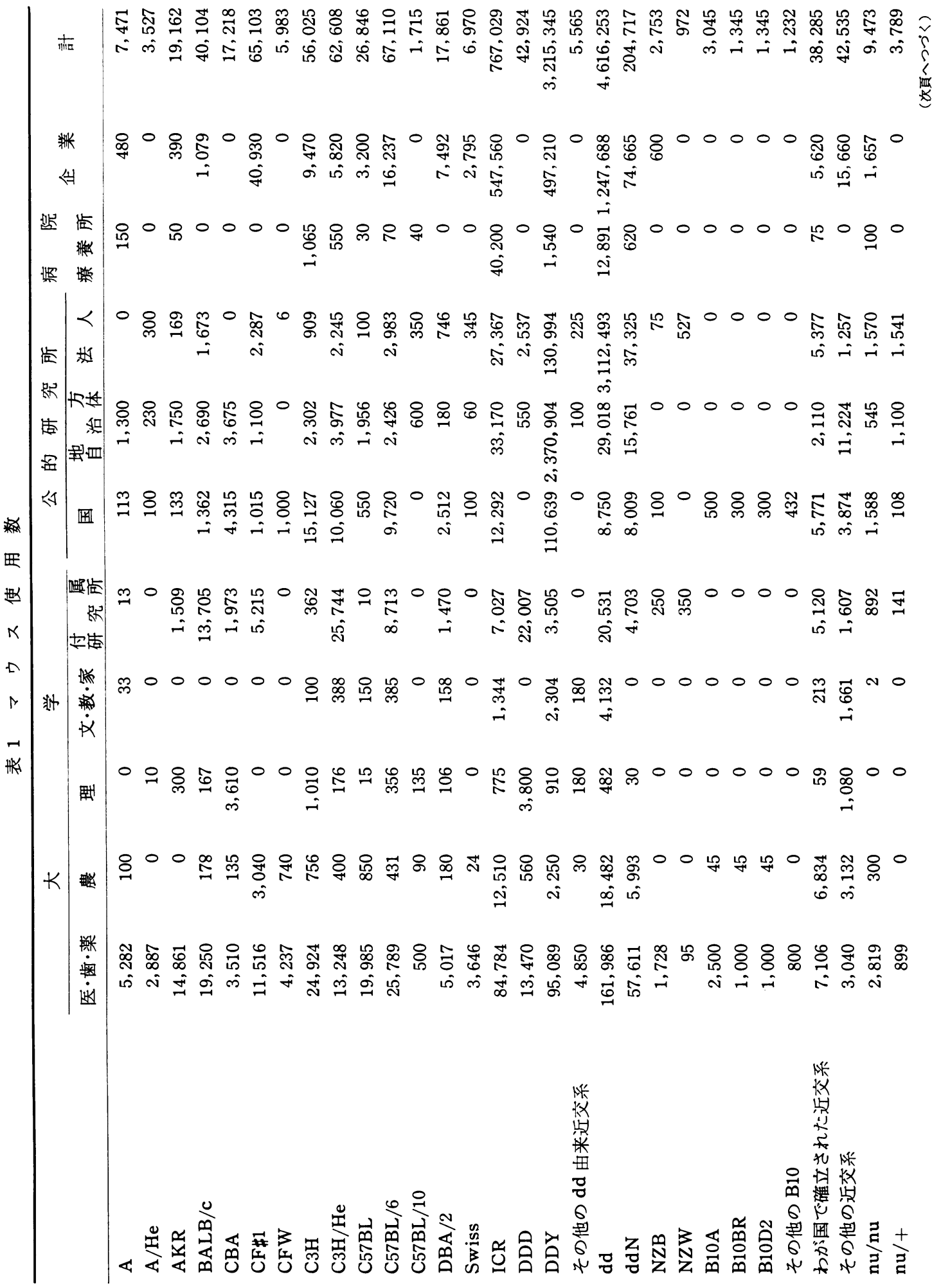




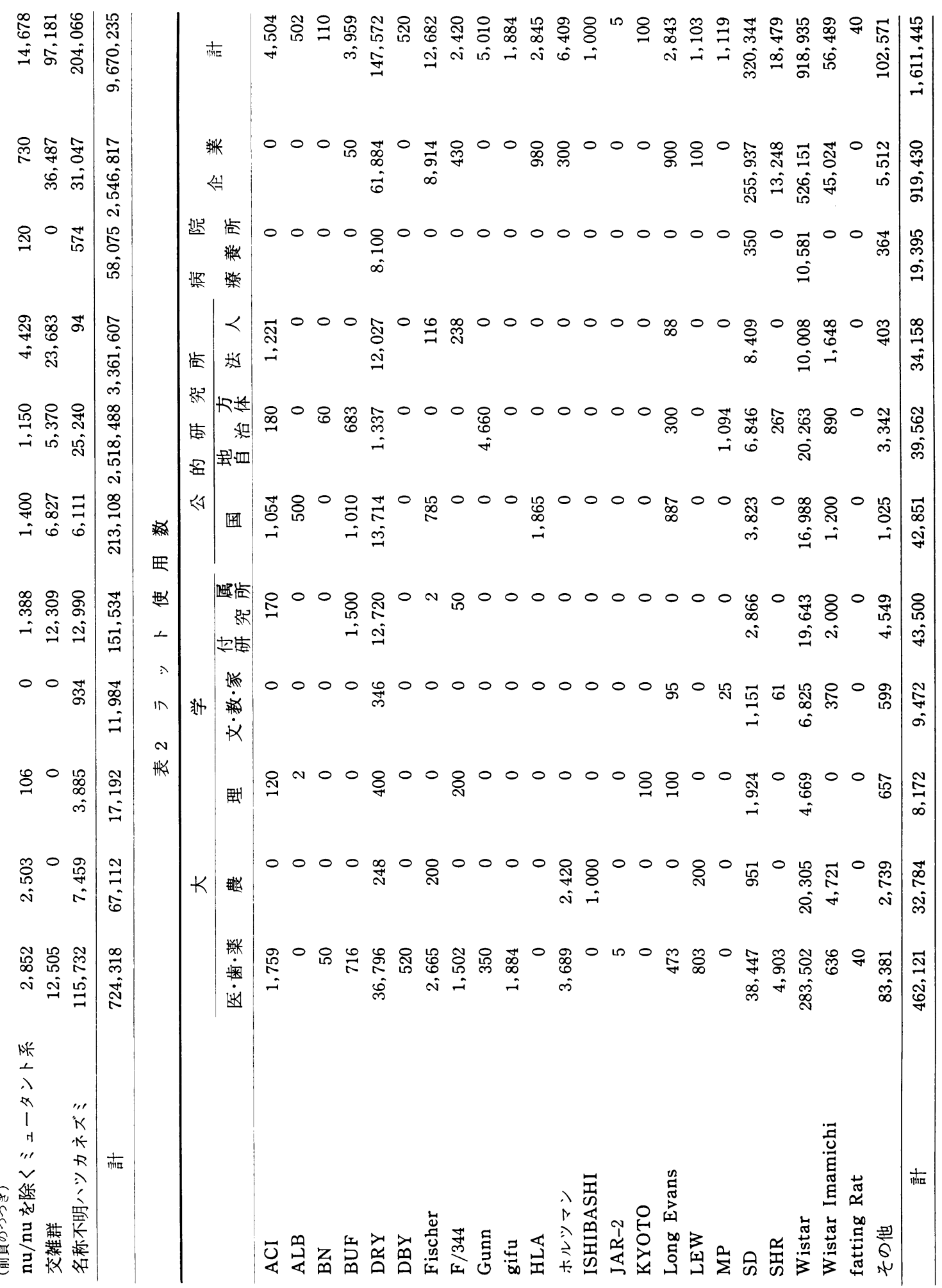



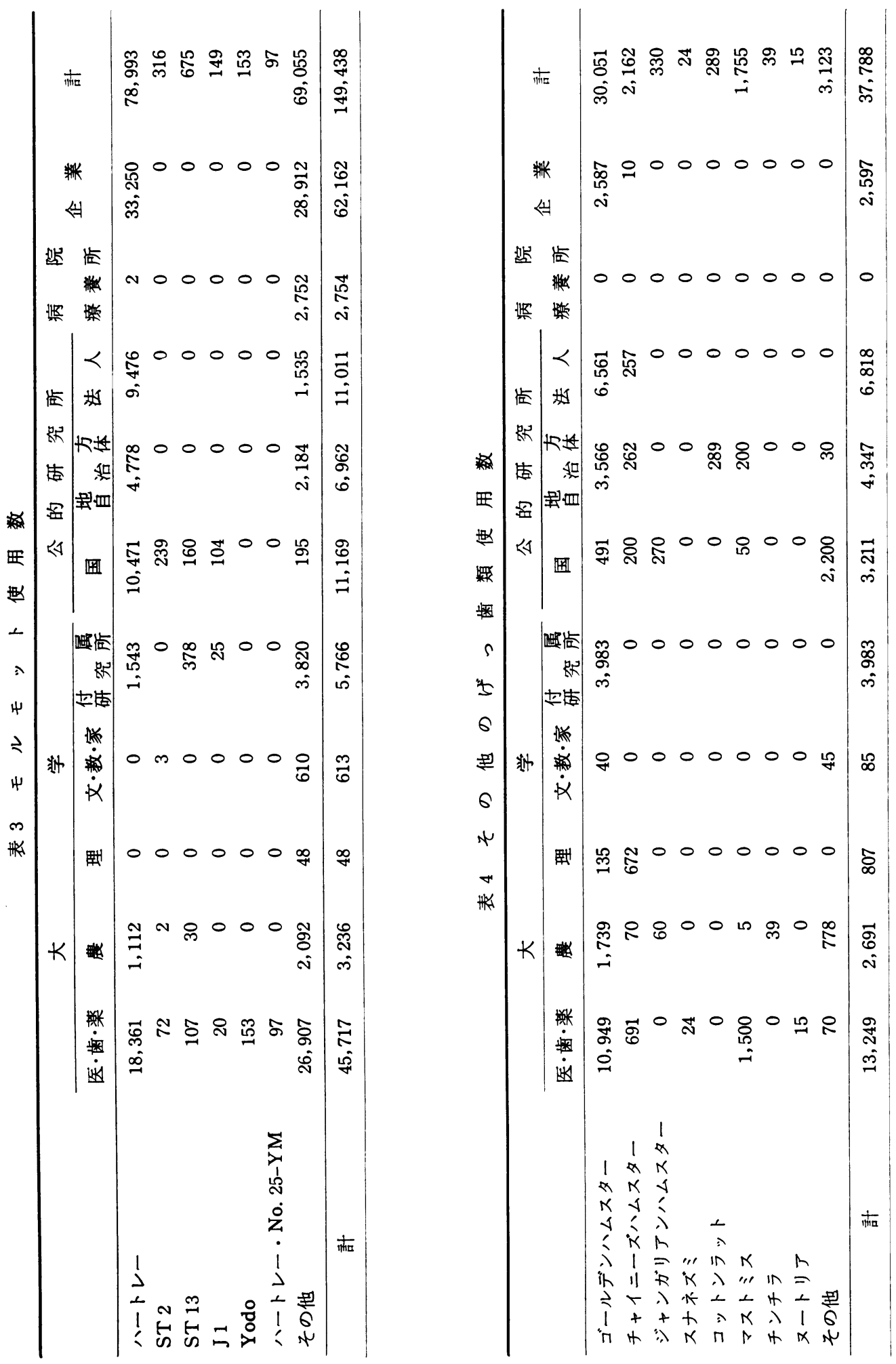

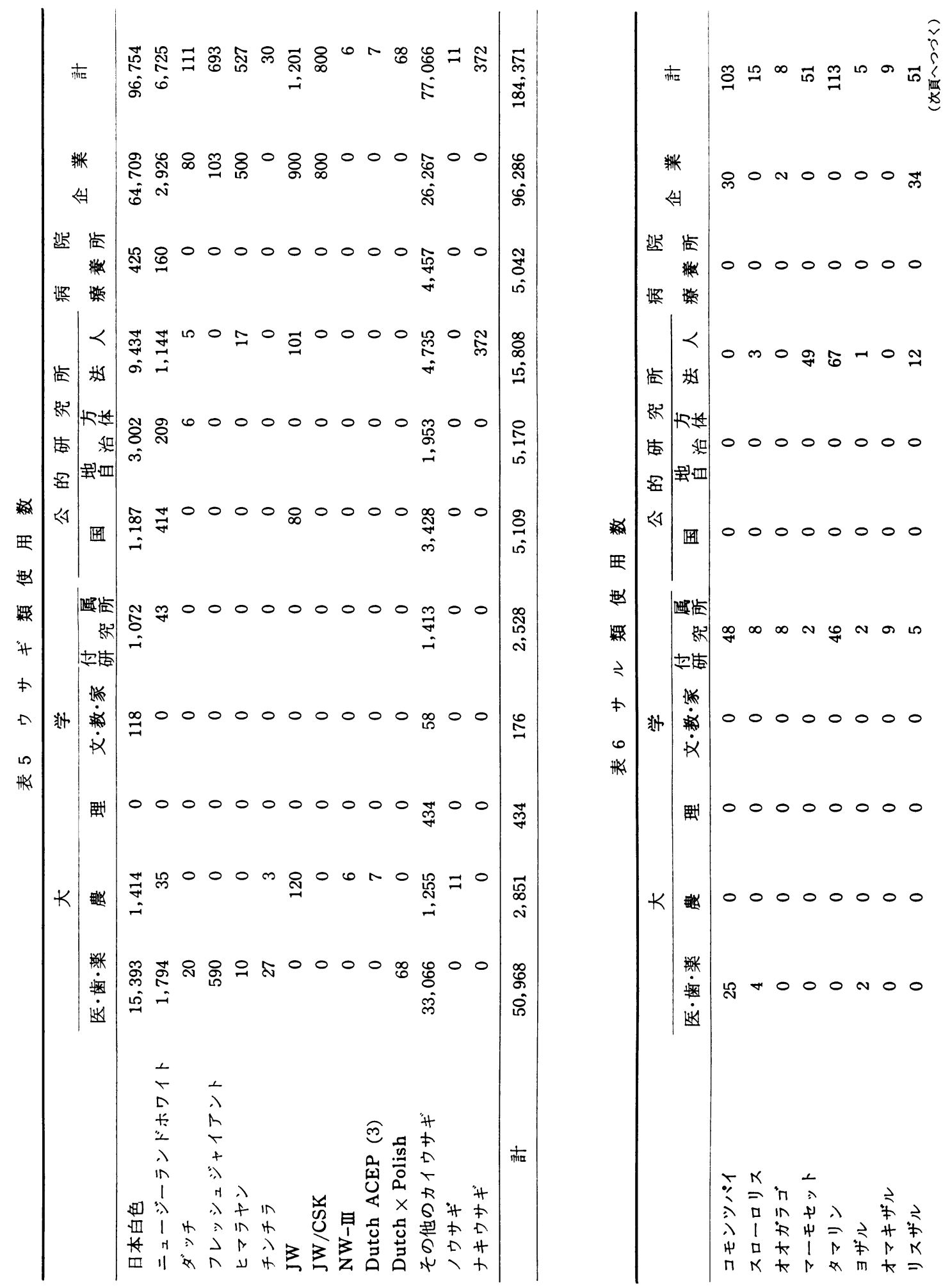


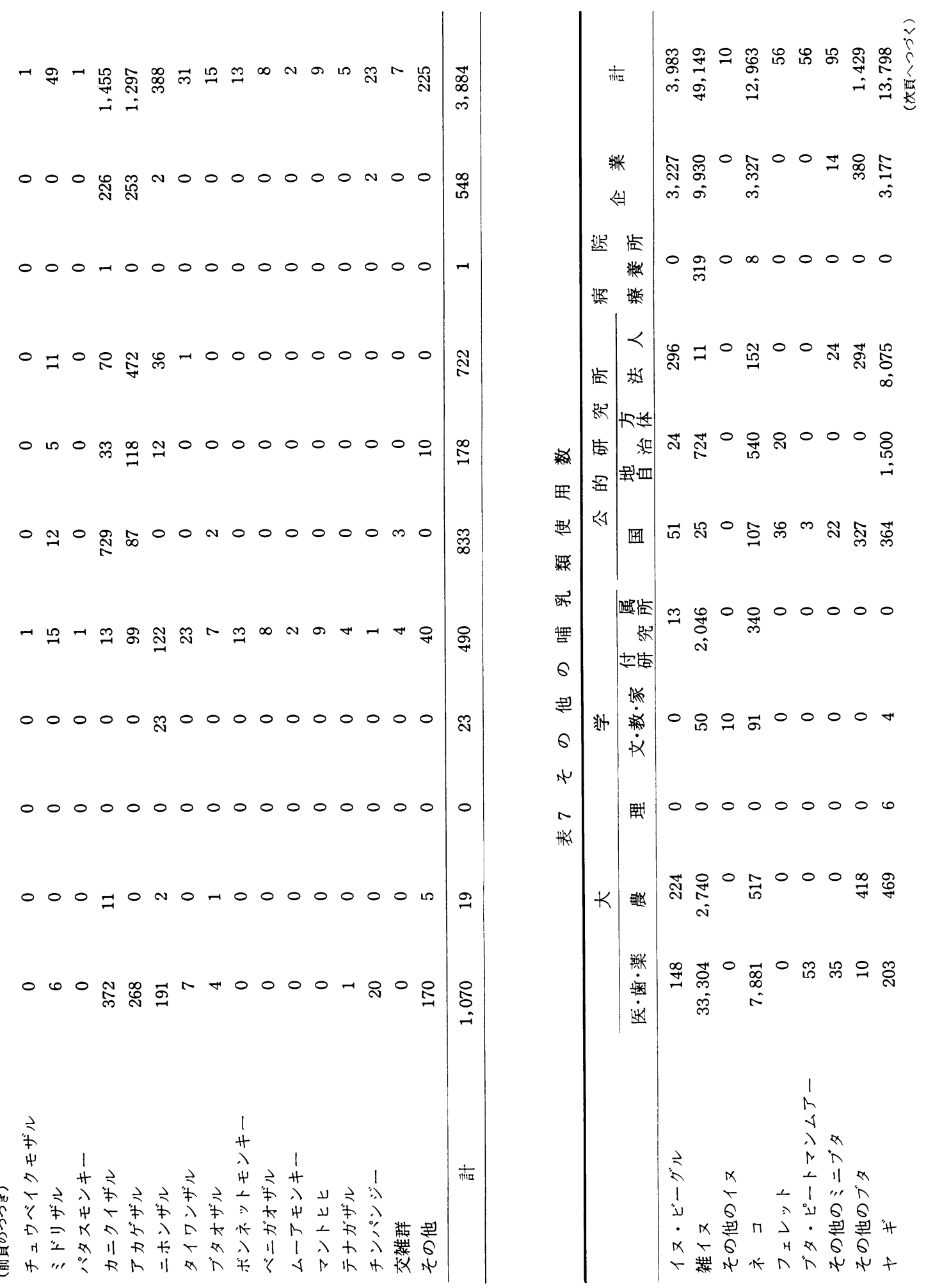




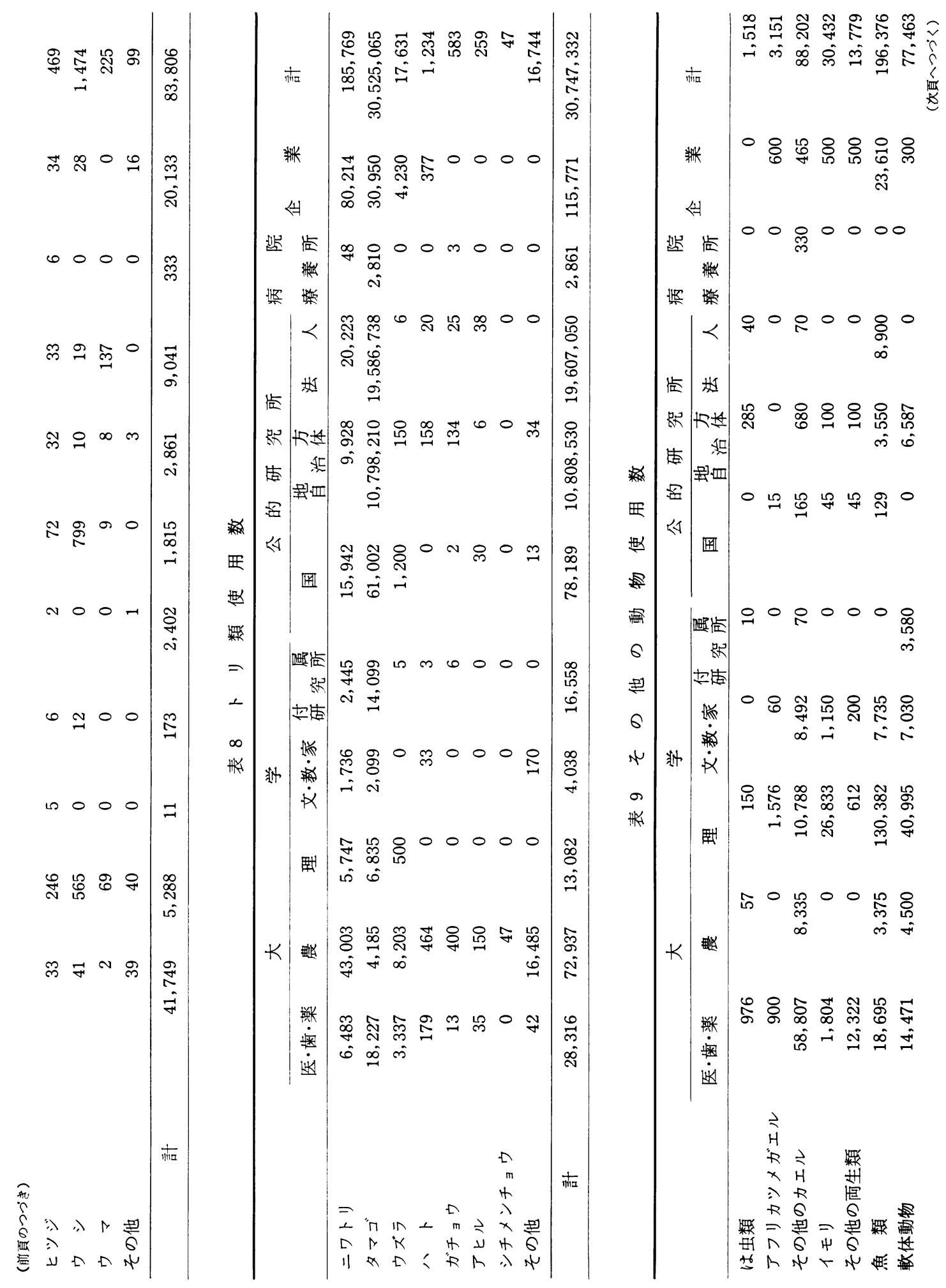




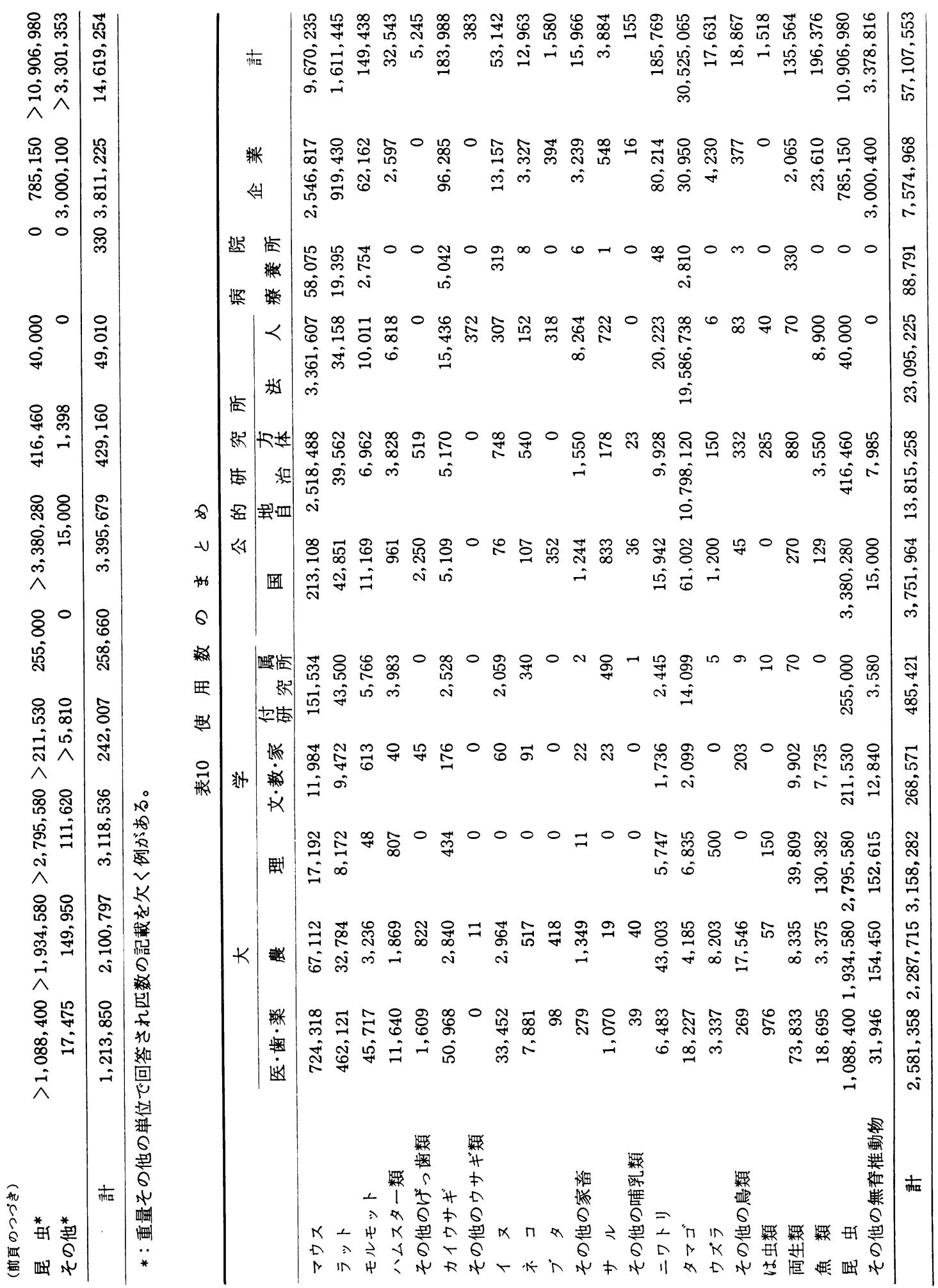

